\title{
Partisipasi Masyarakat Dalam Implementasi Kebijakan Harm Reduction Bagi Pengguna Narkoba di Yayasan Kesehatan Bali
}

\author{
I Dewa Agung Praarsa * \\ * Program Studi Administrasi Publik, Program Pasca Sarjana Universitas Pendidikan \\ Nasional Denpasar, Indonesia
}

Diterima Agustus 2019; Oktober April 2019; Dipublikasikan Desember; 2019

\begin{abstract}
Abstrak
Dalam penelitian ini, implementasi kebijakan harm reduction ialah suatu pendekatan yang berfokus pada konseling, edukasi, maupun penyediaan sarana prasarana bagi pemulihan pengguna narkoba yang tersedia di Yayasan Kesehatan Bali (YAKEBA). Desain pada penelitian ini menggunakan penelitian kualitatif dan menggunakan cara purposive untuk menentukan informan dengan pertimbangan tertentu, yang juga bermaksud untuk memahami fenomena tentang apa yang dialami oleh subjek penelitian. YAKEBA menjadi organisasi/lembaga yang turut serta melaksanakan kebijakan harm reduction, dan akan menjadi topik dalam penelitian ini. Dari hasil penelitian yang didapat, implementasi harm reduction berlangsung dengan baik dan didukung dengan partisipasi masyarakat di lini adat, stakeholder, hingga keluarga pengguna narkoba apabila dilihat dari faktor-faktor yang mempengaruhi implementasi kebijakan harm reduction, meskipun terdapat beberapa kendala seperti ketersediaan kondom yang terbatas, hingga masih kurangnya tenaga medis untuk memaksimalkan pelaksanaan kebijakan harm reduction. Walaupun begitu besar harapan ke depan implementasi kebijakan harm reduction di YAKEBA dapat mendukung keberlanjutan hidup pengguna narkoba.
\end{abstract}

Kata kunci : Partisipasi Masyarakat, Implementasi Kebijakan, Harm Reduction, Pengguna Narkoba

\begin{abstract}
In this study, the implementation of the harm reduction policy is an approach that focuses on counseling, education, and providing infrastructure for the recovery of drug users available at YAKEBA. The design in this study uses qualitative research and uses purposive methods to determine informants with certain considerations, which also intends to understand the phenomenon of what is experienced by the research subject. YAKEBA is an organization/institution that participates in implementing the harm reduction policy, and will be the topic of this research. From the results of the research obtained, the implementation of harm reduction takes place well and is supported by community participation in the line of tradition community, stakeholders, and families of drug users when viewed from the factors that influence the implementation of harm reduction policies, although there are some constraints such as limited availability of condoms, until there is still a lack of medical personnel to maximize the implementation of the harm reduction policy. Even so, the future hopes of implementing the harm reduction policy at YAKEBA can support the survival of drug users
\end{abstract}

Keywords : Public Participation, Implementation of Policies, Harm Reduction, Drug Users

How to Cite : Praarsa, Dewa. A.I. (2019). Partisipasi Masyarakat Dalam Implementasi Kebijakan Harm Reduction Bagi Pengguna Narkoba di Yayasan Kesehatan Bali, 7 (12) : 1-11

\begin{tabular}{lr}
\hline *Corresponding author: & P-ISSN-2549-9165 \\
E-mail: agungpraarsa02@yahoo.com & e-ISSN -2580-2011
\end{tabular}




\section{PENDAHULUAN}

Terbentuknya Undang-Undang Nomor 35 Tahun 2009 didasari atas kewajiban pemerintah dalam memenuhi kebutuhan masyarakat berkaitan dengan aspek kesehatannya yang disertai dengan peningkatan derajat kesehatan masyarakat tersebut. Masyarakat secara luas dipandang sebagai salah satu aset penunjang pembangunan nasional yang berkontribusi terhadap kemajuan bangsa, maka dipandang layak untuk mendapatkan perhatian oleh pemerintah.

Undang-Undang Nomor 35 Tahun 2009 menjadi salah satu gambaran bagaimana narkoba di satu sisi sangat dibutuhkan dalam pelayanan medis, bahkan narkoba juga diharapkan bisa memberikan kontribusi terhadap perkembangan ilmu pengetahuan yang berkaitan dengan dunia medis di masa mendatang. Namun di sisi lain narkoba juga memberikan dampak buruk yang luar biasa apabila penggunaannya telah melewati batas aman konsumsi, sehingga penggunaan narkoba disini telah melanggar peraturan perundangundangan tindak pidana narkotika.

Narkoba yang berada di luar pengawasan pemerintah dikhawatirkan menimbulkan ketergantungan bagi para penggunanya. Jika narkoba telah menimbulkan ketergantungan, maka telah keluar dari peruntukan pemanfaatan narkoba sebagai obat pendukung kesehatan bagi seseorang yang sedang mengalami masalah kesehatan. Efek ketergantungan narkoba yang tidak terkendali, sudah dapat dipastikan akan menimbulkan keresahan bagi masyarakat. Sebab apabila seseorang sudah ketergantungan terhadap narkoba, maka akan mengalami permasalahan kesehatan dan akan dikucilkan oleh masyarakat karena takut menderita hal yang sama seperti pengidap narkoba. Keresahan yang ditimbulkan akibat dari dampak ketergantungan narkoba juga telah merugikan masyarakat dalam hal materi dan memberikan bahaya yang sangat besar terhadap keberlangsungan generasi muda yang akan datang serta ketahanan nasional bangsa Indonesia.

Data laporan World Drug Report mengindikasikan usia yang memiliki tingkat kerentanan dalam memulai penggunaan narkoba (periode resiko kritis), disumbang oleh usia remaja awal berumur 12-14 tahun hingga periode akhir 15-17 tahun, dan mungkin memuncak di usia 18-25 tahun. Kematian secara langsung yang ditimbulkan akibat penyalahgunaan 
obat narkoba, secara global meningkat sebanyak 60 persen dalam kurun waktu dari tahun 2000 hingga 2015, dengan angka kematian 27 persen pada umur yang berusia sekitar 50 tahun ke atas pada tahun 2000, diiringi peningkatan sejumlah 39 persen pada tahun 2015. Penggunaan narkoba didominasi oleh kalangan pria dibandingkan perempuan, sebab perempuan memulai penggunaan narkoba cenderung lebih lambat.

Dengan segala hambatan dan rintangan yang dihadapi oleh bangsa Indonesia, narkoba mendapatkan perhatian khusus sebab dianggap sebagai ancaman yang cukup serius. Di beberapa kesempatan yang lalu Presiden Republik Indonesia, Joko Widodo, mengumumkan pada seluruh masyarakat Indonesia bahwa saat ini Indonesia berada dalam status darurat narkoba. Pernyataan Presiden ini didasari fakta bahwa 30 orang setiap harinya meninggal akibat mengkonsumsi narkoba. Para pengguna yang terdata terbukti hampir di banyak kalangan, dan tidak memandang usia.

Tabel. 1 Jumlah Penyalahguna Narkoba Berdasarkan Kelompok Usia Tahun 2012-2015

\begin{tabular}{cccccc}
\hline \multirow{2}{*}{ No. } & Kelompok Usia & \multicolumn{4}{c}{ Jumlah Pengguna (Orang) } \\
\cline { 3 - 6 } & & 2012 & 2013 & 2014 & 2015 \\
\hline 1. & $<15$ tahun & 134 & 65 & 40 & 874 \\
\hline 2. & $15-20$ tahun & 941 & 425 & 320 & 4.253 \\
\hline 3. & $21-25$ tahun & 2.262 & 785 & 421 & 4.199 \\
\hline 4. & $26-30$ tahun & 4.399 & 1.348 & 634 & 3.505 \\
\hline 5. & $31-35$ tahun & 3.592 & 1.312 & 832 & 3.164 \\
\hline 6. & $36-39$ tahun & 1.454 & 626 & 430 & 1.910 \\
\hline 7. & $>40$ tahun & 820 & 419 & 188 & 1.977 \\
\hline 8. & Tidak terdata & - & - & - & - \\
\hline & Jumlah & 13.602 & 4.980 & 2.865 & 19.882 \\
\hline
\end{tabular}

Sumber: Jurnal Data Puslitdatin BNN Tahun 2017 (Data Diolah)

Penanganan kasus narkoba di Indonesia juga memanfaatkan strategi khusus agar setidaknya dapat mengurangi jumlah peredaran narkoba di Indonesia secara perlahan-lahan. Strategi tersebut diantaranya dengan jalan memutus rantai ekosistem supply (pasokan) dan demand (permintaan). Apabila demand dapat dikurangi dengan bertahap, maka ke depannya supply otomatis menurun menjadi terkikis hingga habis.

Penanganan pengguna narkoba membutuhkan langkah-langkah yang lebih manusiawi, serta mengedepankan pendekatan maupun melalui dukungan sosial dengan tujuan agar pengguna narkoba tidak kembali menggunakan 
narkoba ke depannya. Hal ini sejalan dengan hasil penelitian yang dilakukan oleh (Aztri, dkk, 2013) yang menemukan fakta bahwa ada beberapa kondisi yang terjadi pada pengguna narkoba. Kondisi yang pertama, kelompok teman sebaya yang negatif akan memperkenalkan dan mengantarkan seseorang pada perilaku kecanduan.

Kondisi kedua, dukungan sosial memiliki peranan yang penting dalam proses penyembuhan kecanduan narkoba. Dukungan sosial yang berasal dari orang-orang terdekat pecandu, seperti orangtua dan teman terdekat pecandu akan sangat membantu dalam pemulihan dari dampak penggunaan narkoba. Dukungan dari orang-orang terdekat pecandu membuat pecandu merasa dirinya masih berharga.

Kondisi yang ketiga, harapan akan masa depan yang diperoleh dari pelajaran hidup dan keinginan untuk melakukan perubahan yang terdapat dalam diri pecandu juga berperan dalam proses penyembuhan kecanduan narkoba. Adanya harapan akan masa depan dalam diri pecandu akan menjadi motivasi bagi pecandu untuk memperbaiki kualitas hidup mereka dan terbebas dari narkoba secara perlahan.

\section{METODE PENELITIAN}

Desain pada penelitian ini menggunakan penelitian kualitatif yang didasarkan pada upaya membangun pandangan mereka yang diteliti secara rinci, dibentuk dengan kata-kata, gambaran holistik dan rumit. Penelitian kualitatif adalah penelitian yang bermaksud untuk memahami fenomena tentang apa yang dialami oleh subjek penelitian misalnya perilaku, persepsi, motivasi, tindakan, secara holistik, dan dengan cara deskripsi dalam bentuk kata-kata dan bahasa, pada suatu konteks khusus yang alamiah dan dengan memanfaatkan berbagai metode alamiah (Moleong, 2014). Penelitian ini akan mengunakan metode deskriptif kualitatif, yaitu metode yang memperoleh data seperti hasil pengamatan, hasil wawancara, hasil pemotretan, analisis dokumen, catatan lapangan, disusun peneliti di lokasi penelitian, tidak dituangkan dalam bentuk dan angka-angka (Gunawan, 2014).

Metode penelitian deskriptif kualitatif dilakukan secara intensif, peneliti ikut dalam berpartisipasi lama di lapangan, mencatat secara hati-hati apa yang terjadi, melakukan analisis reflektif terhadap berbagai dokumen yang ditemukan di lapangan (Sugiyono, 
2008). Penelitian ini akan melakukan analisa terhadap data baik itu melalui wawancara, pengolahan data di lapangan, dan lain sebagainya, yang akan dituangkan dalam bentuk uraian naratif.

Sumber data yang akan digunakan dalam penelitian ini adalah berasal dari data primer dan sekunder. Data primer adalah data yang didapat langsung dari lokasi penelitian, sedangkan data sekunder adalah data yang bersumber dari literatur, maupun referensi lainnya (sumber tidak langsung) (Marzuki, 1987). Sementara menurut Lofland dan Lofland (dalam Moleong 2014). Sumber data primer dalam penelitian kualitatif adalah kata-kata, dan tindakan. Sumber data sekunder merupakan dokumen, foto, dan statistik. Maka dalam penelitian ini, data akan diperoleh lewat hasil pengumpulan data yang dilakukan di lapangan, antara peneliti dengan narasumber di Yayasan Kesehatan Bali, kegiatan dalam ruang lingkup harm reduction, hingga mengumpulkan data yang berasal dari beragam literatur.

Menurut (Sugiyono, 2008) pengumpulan data dapat dilakukan dalam berbagai setting, berbagai sumber, dan berbagai cara. Bila dilihat dari settingnya data dapat dikumpulkan pada setting alamiah. Teknik pengumpulan data dalam penelitian dapat dilakukan dengan menggunakan tiga metode yaitu observasi, wawancara, dan dokumentasi.

HASIL DAN PEMBAHASAN

Mekanisme

Pelaksanaan

Implementasi Kebijakan Harm Reduction bagi Pengguna Narkoba di Yayasan Kesehatan Bali

Peraturan Menteri Kesehatan

Nomor 55 Tahun 2015 telah menjadi bagian dari paket intervensi komperehensif atau yang lebih populer dikenal sebagai penanggulangan dampak buruk (harm reduction), dengan basis pelaksanaan yang dapat dilakukan pada institusi layanan kesehatan atau masyarakat. Di YAKEBA sendiri harm reduction yang mengingat pada awalnya hanya bagi narkoba suntik dan dengan mengalami penurunan tren sejauh ini, sekarang YAKEBA juga akan melakukan langkah pengembangkan untuk mengetahui dampak yang ditimbulkan dari perilaku seks pengguna narkobanya.

Kerangka waktu pelaksanaan sembilan komponen harm reduction dilakukan selama hari kerja dimulai pada hari senin-jumat dari pukul 09.0017.00 wita, namun tidak ditentukan secara pasti dan bersifat fleksibel sesuai kebutuhan. Hal ini berbeda dengan kerangka waktu fase intensif dan non 
intensif yang memiliki kerangka waktu yang jelas. Selama melakukan penindakan layanan terapi ini, YAKEBA selalu menjalani kesepakatan dengan klien untuk mendapatkan persetujuan layanan terapi.

Pihak yang diikutsertakan selama program terapi harm reduction di YAKEBA, terutama adalah orang-orang yang memiliki perilaku beresiko terhadap penyakit menular seperti pengguna narkoba suntik hingga pelaku yang memiliki perilaku seks bebas, dengan harapan agar dapat mencegah penyakit HIV semakin berkembang yang disebabkan perilaku beresiko tersebut. Pengguna yang bisa ikut serta dalam program harm reduction di YAKEBA adalah pengguna yang telah abstinent atau yang tidak menggunakan narkoba kembali, telah dirujuk oleh pihak Markas Besar Kepolisian Republik Indonesia, serta tidak sedang menjalani proses hukum, karena diharapkan menjadi contoh atau role model bagi pihak luar.

Wilayah dan titik lokasi yang biasanya jadi perhatian adalah daerah Denpasar dan Badung khususnya, dan umumnya di seluruh kota dan kabupaten seluruh Provinsi Bali, dengan lokasi titik hotspot pecandu yang didapat dari hasil pemetaan sebelumnya. Hambatan lain ditemui selama kegiatan harm reduction adalah kesadaran pengguna untuk melaporkan kondisinya apabila sudah selesai menjalankan kegiatan harm reduction, dan tren penggunaan narkoba yang telah berubah. Pandangan dari YAKEBA sendiri mengenai peraturan HR secara umum dirasakan sudah baik karena disempurnakan dan disederhanakan.

Keseluruhan terapi hr hingga detik ini belum mengalami penolakan dan justru memperoleh dukungan dari seluruh keluarga klien, karena mereka ingin anggota keluarganya berhenti menggunakan narkoba. Terapi harm reduction menjadi salah satu bentuk kebijakan yang bertujuan untuk mengembalikan fungsi seorang pengguna narkoba agar kembali hidup sehat dan dapat diterima oleh seluruh masyarakat. Sehingga pada umumnya masyarakat mengharapkan program terapi ini terus berlanjut dan mendukung berbagai kegiatan terapi yang ada.

Strategi Implementasi Kebijakan Harm Reduction bagi Pengguna Narkoba di Yayasan Kesehatan Bali

Aturan dasar hukum dan pedoman teknis pelaksanaan sembilan komponen terapi harm reduction di YAKEBA adalah Permenkes Nomor 55 Tahun 2015. Kerangka waktu pelaksanaan sembilan 
komponen harm reduction dilakukan selama hari kerja dimulai pada hari senin-jumat dari pukul 09.00-17.00 wita, namun tidak ditentukan secara pasti dan bersifat fleksibel sesuai kebutuhan.

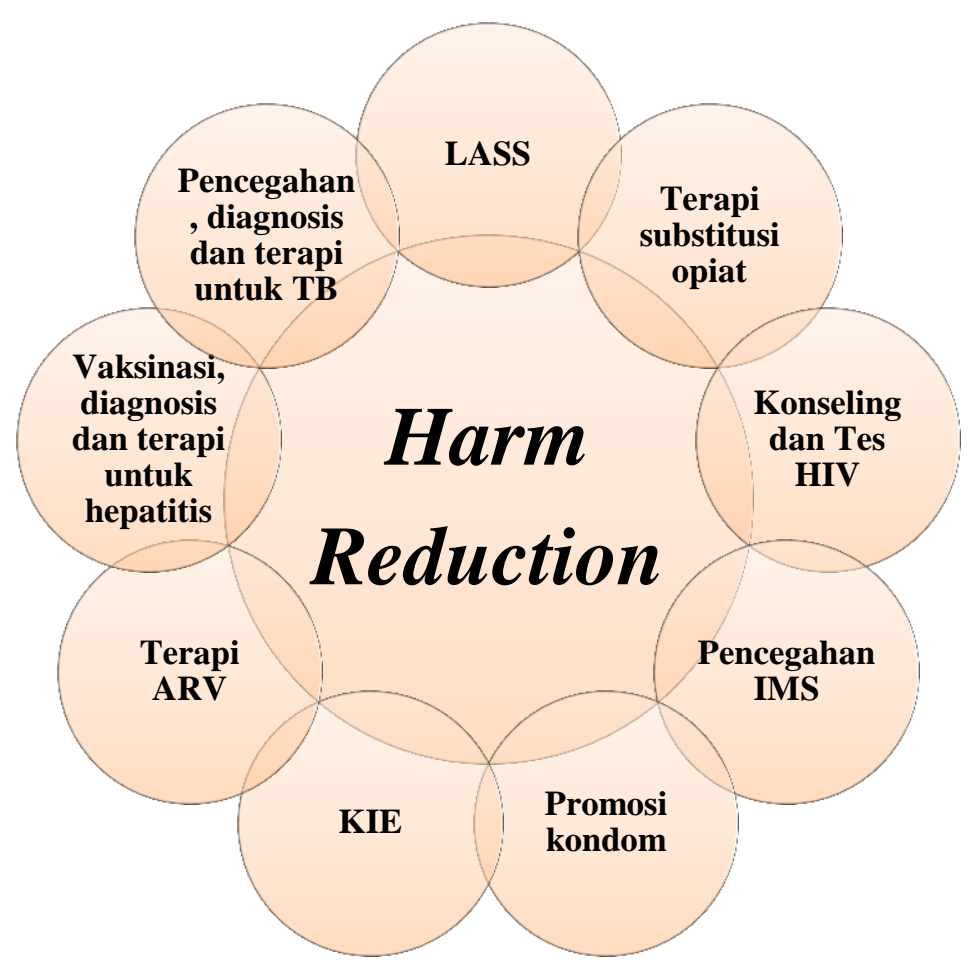

Gambar 1. Sembilan Komponen Harm Reduction di YAKEBA

Sumber: Data Diolah oleh Peneliti tahun 2019 
Faktor-faktor yang Mempengaruhi Implementasi Kebijakan Harm Reduction bagi Pengguna Narkoba di Yayasan Kesehatan Bali

Adapun faktor-faktor yang

mempengaruhi implementasi harm reduction di Yayasan Kesehatan Bali yaitu :

Komunikasi

Upaya komunikasi yang sedang diterapkan di YAKEBA berdasarkan teori, mencerminkan pengelolaan kebijakan yang dapat mengkomunikasikan dan memelihara kepatuhan, khususnya mengenai persoalan pelaksanaan program. Hal itu dapat dilihat dari pencegahan kekambuhan (relaps) yang suatu ketika akan terjadi apabila tidak dapat ditangani sejak dini. Pencegahan kekambuhan penggunaan narkoba oleh klien dilakukan melalui dua pendekatan komunikasi melalui penyampaian konseling dan edukasi, yakni pendekatan internal secara konseling terhadap klien (dengan konseling keterampilan menolak) dan pendekatan eksternal untuk meningkatkan kedisiplinan selepas terapi (dengan edukasi melalui pernyataan form sebagai bentuk komitmen) yang diharapkan dapat meminimalisir terjadinya kekambuhan penggunaan zat narkoba yang diakibatkan oleh pengaruh eksternal.

\section{Sumber Daya}

Edward III, (dalam Subarsono, 2006) berpendapat bahwa sumber daya yang mencukupi didukung melalui sumber daya manusia (keahlian dari implementor). Kemampuan konselor di YAKEBA secara khusus tetap diarahkan untuk mendukung segala potensi yang dimiliki oleh klien, agar klien mampu mandiri selepas pelaksanaan terapi. Bentuk dukungan konselor tersebut seperti menerapkan latihan perilaku masyarakat pada umumnya, hingga tetap mendorong keluarga klien untuk terus terlibat dalam pemulihkan kondisi klien seperti semula.

\section{Disposisi}

Dijelaskan oleh Brian W.Hogwood dan Lewis A.Gunn (dalam Wahab 2004), untuk dapat mengimplementasikan kebijakan publik yang tepat maka perlu pemenuhan persyaratan tertentu, salah satunya yakni: Instansi pelaksana yang menghadapi langsung kondisi eksternal harus memastikan tidak akan adanya timbul kendala yang serius. Sebab beberapa kendala terkadang berada di luar kendali para administrator pada saat implementasi kebijakan, dan penyebab kendala tersebut juga memang berada di luar jangkauan wewenang kebijakan dan instansi pelaksana. 
YAKEBA harus segera menindaklanjuti atas himbauan mengenai penyediaan kondom tersebut, yang tentunya menjadi kebutuhan bagi beberapa populasi kunci/klien. Himbauan ini juga dapat menjadi solusi guna memenuhi persediaan kondom yang saat ini dalam jumlah terbatas. Hal ini tentunya juga memerlukan pendataan yang jelas seperti daftar nama penerima kondom, agar Kemenkes dapat mengetahui lebih rinci mengenai siapa saja yang menerima distribusi kondom tersebut, dan mempermudah penerimaan distribusi kondom ke masing-masing populasi kunci/klien.

\section{Struktur Organisasi}

Charles O. Jones (dalam Subarsono, 2006), berpendapat apabila untuk menunjang segala kegiatan diperlukan, birokrasi/organisasi harus mampu mengkomunikasikan dengan baik ke pihak yang membuat kebijakan serta dengan pihak yang melaksanakan kebijakan. Organisasi dalam hal ini YAKEBA telah melakukan fokus perencanaan terapi dan tidak mengutamakan penghakiman atau juga stigma selama melaksanakan terapi, yang menjadi bagian dalam menunjang segala kegiatan harm reduction.
Dengan keterlibatan berbagai sektor seperti layanan kesehatan dan instansi yang lainnya, kebutuhan dalam upaya mengintensifkan layanan sosial dan kesehatan bagi pengguna narkoba menjadi terpenuhi. Namun menurut Daniel Mazmanian dan Paul A.Sabatier (dalam Subarsono 2006), seharusnya hubungan ketergantungan harus kecil, yang hanya membutuhkan badan pelaksana tunggal.

Keberhasilan implementasi program akan kemungkinan semakin berkurang, bila pelaku yang terlibat cukup besar. Adapun kelemahan dari YAKEBA masih erat ketergantungannya terhadap layanan rujukan, yang disebabkan oleh kurangnya tenaga medis. Hal ini yang menyebabkan YAKEBA tidak terlibat secara penuh selama terapi harm reduction, meskipun klien di YAKEBA tetap didampingi ketika melakukan layanan rujukan.

\section{Ekonomi, Sosial, dan Politik}

Donald Van Meter dan Carl Van Horn (dalam Subarsono, 2006) berpendapat bahwa suatu kebijakan dapat dipengaruhi oleh berbagai kondisi ekonomi, sosial, dan politik. Baik itu dari segi kecukupan sumber daya ekonomi baik itu anggaran dalam pelaksanaan kebijakan, dukungan unsur masyarakat yang menerima atau menolak, hingga dukungan dari para elit 
politik atau pihak yang berwenang. Pelaksanaan kebijakan harm reduction di Bali khususnya di YAKEBA, tidak ada kendala seperti kelambatan gaji, hingga minim permasalahan mengenai pelaksanaannya.

Selain itu MUDP di Bali mendukung secara penuh melalui pemberian edukasi nyiraman layon yang bermanfaat untuk mengurangi terjadinya diskriminasi di kalangan pengguna narkoba yang terpapar HIV. Elit politik di daerah Bali juga menyatakan dukungan penuh untuk mengurangi terjadinya diskriminasi yang terjadi di lapangan, karena layanan kesahatan yang sudah ada, tentunya juga layanan yang ada di pemerintah sudah memadai.

Dukungan setiap stakeholders yang membidangi masing-masing peran dalam mnanggulangi narkoba, sangat diperlukan untuk mendukung setiap bentuk upaya mencegah dampak buruk yang dapat ditimbulkan.

\section{Partisipasi Masyarakat}

Partisipasi masyarakat keberadaannya dianggap penting, seperti yang dikemukakan oleh (Conyers, 1991) karena partisipasi masyarakat merupakan hak dalam era demokrasi dan perlu dilibatkan dalam pembangunan masyarakat mereka sendiri karena mereka akan dapat mengetahui seluk-beluk program tersebut dan akan mempunyai rasa memiliki terhadap program tersebut. Apabila melihat keterlibatan masyarakat dalam bentuk desa adat untuk mengurangi dampak ancaman bahaya narkoba melalui penyusunan pararem, maka diharapkan penanggulangan bahaya narkoba bisa digiatkan kembali di tengah masyarakat. Partisipasi keterlibatan aktif desa adat ini tidak terlepas dari dorongan berbagai pihak, dan tentunya perlu dikembangkan lebih jauh dalam mendukung upaya mencegah peredaran narkoba

\section{KESIMPULAN}

Peraturan Menteri Kesehatan Nomor 55 Tahun 2015 telah menjadi bagian dari paket intervensi komperehensif atau yang lebih populer dikenal sebagai penanggulangan dampak buruk (harm reduction), dengan basis pelaksanaan yang dapat dilakukan pada institusi layanan kesehatan atau masyarakat. Di YAKEBA sendiri harm reduction yang mengingat pada awalnya hanya bagi narkoba suntik dan dengan mengalami penurunan tren sejauh ini, sekarang YAKEBA juga akan melakukan langkah pengembangkan untuk mengetahui dampak yang ditimbulkan dari perilaku seks pengguna narkobanya. 
Pandangan dari YAKEBA sendiri mengenai peraturan HR secara umum dirasakan sudah baik karena disempurnakan dan disederhanakan. Keseluruhan terapi hingga detik ini belum mengalami penolakan dan justru memperoleh dukungan dari seluruh keluarga klien, karena mereka ingin anggota keluarganya berhenti menggunakan narkoba. Terapi harm reduction menjadi salah satu bentuk kebijakan yang bertujuan untuk mengembalikan fungsi seorang pengguna narkoba agar kembali hidup sehat dan dapat diterima oleh seluruh masyarakat. Sehingga pada umumnya masyarakat mengharapkan program terapi ini terus berlanjut dan mendukung berbagai kegiatan terapi yang ada.

\section{UCAPAN TERIMAKASIH}

Terimahkasih kepada pembimbing yang telah memberikan kepercayaan kepada penulis, sehingga telah diberikan kesempatan untuk mengambil bagian dalam topic ini.

\section{DAFTAR PUSTAKA}

Conyers, Diana. 1991. Perencanaan Sosial di Dunia Ketiga. Yogyakarta: UGM Press.

Gunawan, Imam. 2014. Metode Kualitatif Teori dan Praktik. Jakarta: Bumi Aksara.
Laporan Kasus HIV-AIDS, Dinas Kesehatan Provinsi Bali, Maret 2019

Marzuki. 1987. Metodologi Riset. Yogyakarta: BPFE.

Moleong, Lexy. 2014. Metodologi Penelitian Kualitatif. Bandung: Remaja Rosdakarya.

Nawawi, H. 1995. Metode Penelitian Sosial. Yogyakarta: Gajah Mada University Press.

Peraturan Menteri Koordinator Bidang Kesejahteraan Rakyat RI Nomor: 02/Per/Menko/Kesra/I/2007

Tentang Kebijakan Nasional Penanggulangan Hiv Dan Aids Melalui Pengurangan Dampak Buruk Penggunaan Narkotika Psikotropika Dan Zat Adiktif Suntik.

Subarsono, AG. 2006. Analisis Kebijakan Publik, Konsep, Teori dan Aplikasi. Yogjakarta: Pustaka Fajar.

Sugiyono. 2008. Memahami Penelitian Kualitatif. Bandung: Alfabeta.

Surat Edaran No. 4 Tahun 2010 tentang Menempatkan Pemakai Narkoba ke Dalam Panti Terapi dan Rehabilitasi.

Wahab, Abdullah. 2004. Analisis Kebijakan dari Formula Keimplementasian Kebijakan Negara. Jakarta: Bumi Aksara. 